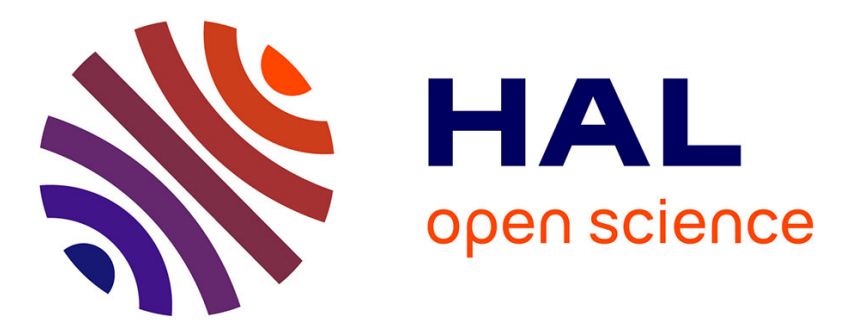

\title{
Gymnocranius superciliosus and Gymnocranius satoi, two new large-eye breams (Sparoidea: Lethrinidae) from the Coral Sea and adjacent regions
}

\author{
Philippe Borsa, Philippe Bearez, Sobar Paijo, Wei-Jen Chen
}

\section{- To cite this version:}

Philippe Borsa, Philippe Bearez, Sobar Paijo, Wei-Jen Chen. Gymnocranius superciliosus and Gymnocranius satoi, two new large-eye breams (Sparoidea: Lethrinidae) from the Coral Sea and adjacent regions. Comptes Rendus Biologies, 2013, 336, pp.233-240. ird-00847880

\author{
HAL Id: ird-00847880 \\ https://hal.ird.fr/ird-00847880
}

Submitted on 24 Jul 2013

HAL is a multi-disciplinary open access archive for the deposit and dissemination of scientific research documents, whether they are published or not. The documents may come from teaching and research institutions in France or abroad, or from public or private research centers.
L'archive ouverte pluridisciplinaire $\mathbf{H A L}$, est destinée au dépôt et à la diffusion de documents scientifiques de niveau recherche, publiés ou non, émanant des établissements d'enseignement et de recherche français ou étrangers, des laboratoires publics ou privés. 
Borsa P, Béarez P, Paijo S, Chen W-J (2013) Gymnocranius superciliosus and Gymnocranius satoi, two new large-eye breams (Sparoidea: Lethrinidae) from the Coral Sea and adjacent regions. C R Biol 336, 233-240.

Gymnocranius superciliosus and Gymnocranius satoi, two new large-eye breams (Sparoidea: Lethrinidae) from the Coral Sea and adjacent regions

Gymnocranius superciliosus et Gymnocranius satoi, deux nouveaux bossus blancs (Sparoidea : Lethrinidae) de la mer de Corail et des régions adjacentes

Philippe Borsa a, ${ }^{\text {, }}$ Philippe Béarez b ${ }^{b}$, Sobar Paijo c, Wei-Jen Chen ${ }^{d}$

a Institut de recherche pour le développement (IRD), Nouméa, New Caledonia

b Museum national d'histoire naturelle, Paris, France

c Proyek BarKor, Jl Pelabuhan Boswesen, Sorong, West Papua

${ }^{\mathrm{d}}$ Institute of Oceanography, National Taiwan University, Taipei, Taiwan

${ }^{*}$ Author for correspondence: IRD-UR 227, Centre de Montpellier, 911 avenue Agropolis, 34394 Montpellier cx, France; e-mail addresses: philippe.borsa@ird.fr; philippeborsa@gmail.com (P. Borsa) 


\section{A B S T R A C T}

Two related perciform fish species of the subfamily Monotaxinae (Sparoidea: Lethrinidae) Gymnocranius superciliosus sp. nov. and Gymnocranius satoi sp. nov. are described from specimens and tissue samples from the Coral Sea and adjacent regions. Gymnocranius superciliosus sp. nov. is distinct from all other known Gymnocranius spp. by the following combination of characters: body elongated (depth 2.7-3.1 in standard length), caudal fin moderately forked with a subtle middle notch, its lobes slightly convex inside, distinctive blackish eyebrow, snout and cheek with blue speckles, and dorsal, pectoral, anal and caudal fins reddish. Gymnocranius satoi sp. nov. is the red-finned 'Gymnocranius sp.' depicted in previous taxonomic revisions. While colour patterns are similar between the two species, Gymnocranius satoi sp. nov. is distinct from Gymnocranius superciliosus sp. nov. by the ratio of standard length to body depth (2.4-2.5 vs. 2.7-3.1) and by the shape of the caudal fin, which is more shallowly forked, its lobes convex inside and their extremities rounded. The two species are genetically distinct from each other and they are genetically distinct from G. elongatus, G. euanus, G. grandoculis, and G. oblongus sampled from the Coral Sea and adjacent regions.

Keywords

Gymnocranius sp.; Torao Sato; New Caledonia; cytochrome $b$

\section{RÉ S U M É}

Deux espèces proches de poissons perciformes de la sous-famille des Monotaxinae (Sparoidea : Lethrinidae) Gymnocranius superciliosus sp. nov. et Gymnocranius satoi sp. nov. sont ici décrites à partir de spécimens et d'échantillons de tissus provenant de la mer de Corail et des régions adjacentes. Gymnocranius superciliosus sp. nov. se distingue de toutes les autres espèces connues du genre par la combinaison de caractères suivante : corps allongé (rapport de la longueur standard à la hauteur du corps : 2.7-3.1), nageoire caudale modérément fourchue présentant une légère encoche en son milieu, ses deux lobes légèrement convexes vers l'intérieur, un sourcil noirâtre distinct, des taches bleues sur le museau et les joues, et les nageoires dorsale, pectorale, anale et caudale rougeâtres. Gymnocranius satoi sp. nov. est le 'Gymnocranius sp.' à nageoires rouges décrit lors de révisions txonomiques antérieures. Alors que les patterns de coloration entre les deux espèces sont semblables, Gymnocranius satoi sp. nov. se différencie de Gymnocranius superciliosus sp. nov. par le rapport de la hauteur sur la longueur standard (2.4-2.5 vs. 2.7-3.1) et par la forme de la nageoire caudale, qui est moins fourchue, aux lobes convexes vers l'intérieur et aux extrémités arrondies. Les deux espèces sont génétiquement distinctes l'une de l'autre, ainsi que des espèces suivantes du genre Gymnocranius, échantillonnées en mer de Corail et dans les régions adjacentes : G. elongatus, G. euanus, G. grandoculis et G. oblongus.

\section{Mots clés}

Gymnocranius sp. ; Torao Sato ; Nouvelle-Calédonie ; cytochrome $b$ 


\section{Introduction}

The taxonomy of large-eye breams (Lethrinidae: Monotaxinae), which comprise large, carnivorous species of the Indo-West Pacific coral reef lagoons and reef slopes, still awaits completion [1,2]. In his revision of the Monotaxinae, Sato [1] noted that specimens labelled "Gymnocranius griseus" (non Temminck and Schlegel 1844 [3]) by Coleman [4] and "Gymnocranius lethrinoides" (non Bleeker 1850 [5]) by Masuda et al. [6] were actually misidentified and he referred to them as an undetermined species, “Gymnocranius sp.". Sato's Gymnocranius sp. is a distinctive, bright-coloured, large-sized (up to $50 \mathrm{~cm}$ ) fish of the reef-associated sandy habitats throughout the Coral Triangle and the western Pacific [1,2]. This fish is occasionally encountered on the stalls of fish markets in southern Japan, western West Papua and the tropical south-western Pacific islands ([2,6]; P. Borsa and S.P., pers. obs.). It is surprising that Sato's Gymnocranius sp. has remained undescribed, nearly three decades after it was first mentioned in the ichthyological literature.

A large-eye bream with reddish fins that resembles Sato's Gymnocranius sp. was first noticed (under "Gymnocranius sp.") at the Nouméa fish market in August 2002 by P. Béarez [7] (Fig. 1A). This fish was slender than Gymnocranius sp. pictured in Masuda et al. [6] (as "G. lethrinoides") and Carpenter and Allen [2], although its body proportions fitted Coleman's [4] “G. griseus” from the Great Barrier Reef. The same species was subsequently sampled from the northern and southern lagoons of New Caledonia's Grande Terre, the Chesterfield islands and Fiji, and proved genetically distinct from Sato's Gymnocranius sp. [8,9]. Inferred genotypes at four size-polymorphic intron loci indicated reproductive isolation between the two species in New Caledonia [9,10]. The two species were provisionally named Gymnocranius sp. B and Gymnocranius sp. C, respectively [9-12]. Gymnocranius sp. B and Gymnocranius sp. C were found to be genetically distinct from other Gymnocranius species from the Coral Sea and adjacent regions, including Gymnocranius elongatus Senta 1973 [13], Gymnocranius euanus (Günther 1879 [14]), Gymnocranius grandoculis (Valenciennes 1830 [15]) and the recently described Gymnocranius oblongus Borsa, Béarez and Chen 2010 [10] [8,9], and reproductively isolated from the three latter [9].

In the present article, we describe Gymnocranius sp. B and Gymnocranius sp. C as, respectively, Gymnocranius superciliosus sp. nov. and Gymnocranius satoi sp. nov. on the basis of morphology, colour patterns, and cytochrome- $b$ nucleotide sequences.

\section{Materials and methods}

The following specimens of Gymnocranius sp. B and Gymnocranius sp. C were collected and examined: Institut de recherche pour le développement, Nouméa (IRDN) no. IRDN-z179 (sp. B, from the northern lagoon of New Caledonia, collected 21 December 2004 at the Nouméa fish market); Museum national d'histoire naturelle, Paris (MNHN) no. MNHN 2009-0010 (sp. B, captured using a demersal 
gillnet, New Caledonia, 21 January 2005); MNHN 2009-0011 (sp. B, demersal gillnet, southern lagoon of New Caledonia, 02 March 2005); MNHN 2009-0012 (sp. B, demersal gillnet, New Caledonia, 07 June 2008); MNHN 2009-0013 (sp. B, demersal gillnet, Viti Levu, Fiji, 19 September 2008); and MNHN 20110103 (sp. C, reportedly from the Lesser Sunda islands, November 2009). Measurements on these specimens were made to the nearest mm using a Vernier calliper. Eight other specimens were examined by either P. Borsa, P. Béarez, S.P., F. Giancarlo (BioKor, Indonesia and West Papua), or J.-L. Justine (IRD, Nouméa) at the time of collection and subsequently re-examined and measured from photographs: IRDN20071124-G3 (sp. C, from Raja Ampat, West Papua, 24 November 2007); IRDN-20080131-A (sp. C, reportedly from the Lesser Sunda islands, collected at the Kedonganan fish market, 31 January 2008);

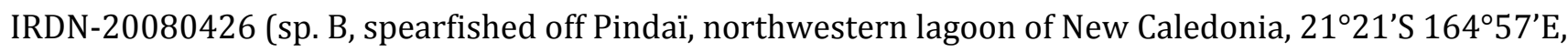
depth 7 m, coral sandy bottom, 26 April 2008); IRDN-20081022 (sp. B, spearfished off Loop islet, Chesterfield Islands, $19^{\circ} 58^{\prime} \mathrm{S} 158^{\circ} 28^{\prime} \mathrm{E}$, depth $5 \mathrm{~m}$, coral sandy bottom, 22 October 2008); J.-L. Justine's (pers. comm.) catalogue no. JNC-583 (sp. C, baited handline, Sournois reef, New Caledonia; JNC-2912 (sp. B, baited handline, Tomboo Pass, New Caledonia, 21 April 2009); JNC-3055 (sp. C, baited handline, pass south of Tomboo reef, New Caledonia, 16 September 2009); MNHN ICOS-00715 (sp. B, New Caledonia, 24 August 2002).

Photographs of the specimens examined are presented in Figs. 1-3 and in Supplementary material, Fig. S1. Specimens MNHN 2009-0010, MNHN 2009-0011, MNHN 2009-0012, MNHN 2009-0013, and MNHN 2011-0103 have been preserved whole. Specimen MNHN ICOS-00715 has been preserved as skeleton. For specimens IRDN-z179, IRDN-20080426, and JNC-2912, only the neurocranium has been preserved. Muscle-tissue or fin-clip samples of the foregoing except MNHN ICOS-00715 have been preserved in 95\% ethanol.

Whole genomic DNA was extracted from fin clips of individuals nos. MNHN 2009-0010 (Gymnocranius sp. B) and IRDN-20071124-G3 (Gymnocranius sp. C) using the Qiagen DNeasy extraction kit (Qiagen, Valencia CA, U.S.A.) according to the manufacturer's instructions. These tissue samples and DNA extracts are nos. Let 20 and Let 19, respectively, in the collections of the Marine Phylogenomics Laboratory at the Institute of Oceanography, National Taiwan University, Taipei. Oligonucleotides Mono14695F (5'- A A G C C A C C G T T G T T A T T C A A C T A -3') and Mono15971R (5'- G A A T G T T A G C T T T G G G A G C T T T T -3') were designed by W.-J.C. to specifically amplify the complete cytochrome $b$ gene in Monotaxinae. Conditions for polymerase-chain amplification reaction (PCR) were as follows: 0.5 units GoTaq ${ }^{\circledR}$ Flexi DNA polymerase (Promega, Madison WI, U.S.A.), 1 x reaction buffer, $2 \mathrm{mM}$ of $\mathrm{MgCl}_{2}$, $200 \mu \mathrm{M}$ of each dNTP, $0.2 \mu \mathrm{M}$ of each primer, and 20-50 ng of genomic DNA in a $25 \mu \mathrm{l}$ of final reaction volume. Thermocycling conditions for PCR were: initial denaturing step at $95^{\circ} \mathrm{C}$ for 4 min followed by 35 cycles of $95^{\circ} \mathrm{C}$ (for $40 \mathrm{~s}$ ), annealing Tm of $55^{\circ} \mathrm{C}$ (for $40 \mathrm{~s}$ ), and $72^{\circ} \mathrm{C}$ (for $1-1.5 \mathrm{~min}$. depending on size of fragments), and then a final extension step of $72^{\circ} \mathrm{C}$ (for $7 \mathrm{~min}$ ) before a $4^{\circ} \mathrm{C}$ soak. Finally, the PCR products were cleaned up following the AMPure magnetic bead cleanup protocol (Agencourt Bioscience Corp., 
Beverly MA, U.S.A.) and resuspended in $30 \mu \mathrm{L}$ sterile water. Sequences were then determined by Macrogen Inc. (Seoul, South Korea) using an ABI 3730xl analyzer (Applied Biosystems, Foster City CA, U.S.A.).

The sequences of these two individuals were aligned with the 315-bp fragments of the cytochrome $b$ gene of G. elongatus, G. euanus, G. grandoculis, G. oblongus, Gymnocranius sp. B, and Gymnocranius sp. C that have been produced previously [8,16], using BioEdit [17].

\section{Gymnocranius superciliosus sp. nov.}

Gymnocranius superciliosus sp. nov. (Table 1; Fig. 1; Fig. 2). Previously referred to as G. griseus (non Temminck and Schlegel 1844 [3]) [4]; Gymnocranius sp. [7,18,19]; and Gymnocranius sp. B [8-12].

\subsection{Vouchers and type material}

Material examined (Table 1; Fig. 1 Fig. 2; Supplementary material, Fig. S1): IRDN-z179 (neurocranium preserved); IRDN-20080426 (neurocranium preserved); IRDN-20081022 (fin clip preserved); JNC-2912 (photo voucher); MNHN 2009-0010 (holotype); MNHN 2009-0011 (paratype); MNHN 2009-0012 (paratype); MNHN 2009-0013 (paratype); MNHN ICOS-00715 (skeleton; paratype).

\subsection{Diagnostic description}

The following diagnosis of Gymnocranius superciliosus sp. nov. is based on the nine specimens whose measurements are given in Table 1. Morphology: a slender Gymnocranius, with ratio of standard length to body depth between 2.65 and 3.06; forehead bumpy; lower edge of eye well above axis of body; caudal fin moderately forked, its lobes slightly rounded. Number of scales rows above lateral line: 6. Pored scales on lateral line: 48 (for 6/9 specimens examined) or 49 (3/9). Colour: flanks silvery; scales above lateral line with a dark-grey basal patch forming longitudinal rows; scales with similar dark-grey basal patch on a more or less extended portion of flank below lateral line; up to two dozens or more pale-blue speckles against bronze background on snout and cheeks, distinctive on fresh, larger individuals, faint on smaller individuals; pale-blue band joining the nostrils on forehead and reaching the eyes, bright in freshly captured, larger individuals; area immediately above eye (supraorbital shelf) forming a distinctive blackish eyebrow; more or less conspicuous vertical dark bar crossing the eye; upper lip reddish to red, lower lip white; dorsal, pectoral, anal and caudal fins reddish to red.

Gymnocranius superciliosus sp. nov. is here described by the nucleotide sequence of its cytochrome $b$ gene (from holotype, MNHN 2009-0010): 5'- A T G G C C A G T C T C C G A A A A A C C C A C C C C C T C C T

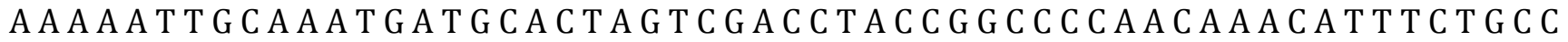




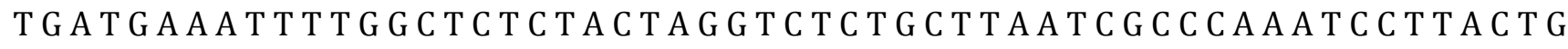
G C C T A T T T C T C G C C A T A CA T T A C A C C T C T GA T A T C G C CACAG C A T T C T C C T C CG T GG C C CA CA T T T G C C GA GA CG T A A A T T C GGA T GA C T C A T T C G T A A C T C C A T G C C A A T GGGGC C T CA T T T T T C T T C A T C T G T A T T TA T C T C CA TA T T G GC C GAGGAT TA T A C T A C GG C T C C T A C C T G T A C A A A GA GA C C T GAAAT A T C G GA G T A G T C C T G C T T C T C C T A G T A A T A A T A A C A G C T T T C G TAGG C T A T G T T C T C C C C TGGGGACAAATA T C T T T T T GA G G T G C C A C C G T C A T C A C T A A C C T C C T C T C C G C A G T G C CA T A T G T A G G A A

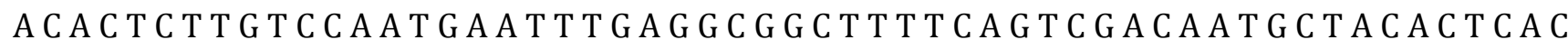
C C G A T T T T T C G C T T T C C A C T T T C T C T T C C C C T T C G T C A T T G CA G C T G CAAC TA T C C T C C A C C T T C T A T T C C T A CACGAAAC C GGATC T AACAAC C C T C TAGG C C T AAAT T CAGACTCAGACAAAAT T T CA T T T CACC C C T A C T T C T C C T A TAAAGACCTGCTAGG T T T C G C A G C T G T C C T GA T CA C C C T C A C C T G T C T A G C A C T T T T C T C C C C C AA C C T T C T T G GA G A C C C G G A C A A C T T C A C A C C T G C GA A C C C C C T C G T G A C C C C T C C C C A T A T TAAAC CAGAGT GA T A C T T T C T A T T C G C G T A C G C CA T T C T A C G T T C A A T T C A A T A A A C T T G G T G G C G T A C T C G C A C T C T T G G C T T C C A T C C T G G T T C T T A T G G T G G T G C C C A T C C T C CACACA T C T A A A C A A CGGAG T T T A A C A T T C C G T C C C C T AACACAAT T T C T C T T T T GA G T T C T T A T T G C CAA T G T T G C C A T T C T T A C C T GAAT T GGAGGAATG C C T G T A GAACAC C C G T T C A T T A T CA T T GGC CAAA T C G CA T C T C T T C T C T A C T T T T CGCTCT T C C T CAT T G C T A T A C CACTAGCAAGT T GATGGGAGAACAAAACT T TAGG T T G A G C T -3'.

\subsection{Etymology}

The epithet superciliosus, meaning 'eyebrowed', was chosen by reference to the conspicuous dark patch above eye, which evokes an eyebrow. This feature is particularly noticeable when the fish is seen underwater ([4,19]; Supplementary material, Fig. S1F). We propose as vernacular name: Eyebrowed large-eye bream.

\subsection{Notes on distribution, habitat and ecology}

Gymnocranius superciliosus sp. nov. was collected by spearfishing at 5-7 $\mathrm{m}$ depth on coral-sand bottom in the northwestern lagoon of New Caledonia's Grande Terre and in the Chesterfield Islands (central Coral Sea) in April 2008 and October 2008, respectively. Samples of this species were also collected using handlines in the southern lagoon of New Caledonia's Grande Terre in March 2006, April 2009 and September 2009 (J.-L. Justine, pers. comm.). It was also sampled from the lagoons of Viti Levu 
and Gau islands in Fiji in September 2008, and from the northern lagoon of New Caledonia in December 2004. See also [19] for the underwater photograph of an individual from Fiji. A specimen was caught on a bottom line by C.A.J. Duffy (pers. comm.) in the south-western lagoon of Nukufetau atoll, Tuvalu in April 2007, "in 15-20 m depth, on a small patch of reef surrounded by sand". Gymnocranius superciliosus sp. nov. has also been reported from Queensland (as "G. griseus") by Coleman [4]. It was also sighted off Pulau Fam in Raja Ampat (West Papua) in December 2007 (P. Borsa, pers. obs.). This species is not mentioned from the Japanese archipelago [6]. It was not found by us among Gymnocranius spp. samples from the Lesser Sunda islands or from southern Sulawesi, where seven other Gymnocranius species including G. elongatus, G. frenatus, G. grandoculis, G. microdon, Gymnocranius satoi sp. nov. and two yet undescribed species (Gymnocranius sp. D and Gymnocranius sp. E) have been observed (P. Borsa and W.J.C., pers. obs.). Therefore, the distribution of Gymnocranius superciliosus sp. nov. may be restricted to the tropical south-western Pacific, but more observations will be necessary to accurately delineate it.

Little is known of the ecology of Gymnocranius superciliosus sp. nov., except that is "encountered around sandy lagoons along the outer Great Barrier Reef and cays of the Coral Sea" [4]. It has been captured by spearfishing on sandy bottom of back-reef lagoon and large pools at depths from 5 to $7 \mathrm{~m}$ in the northwestern lagoon of Grande Terre and in the Chesterfield lagoon. Nouméa fishermen capture Gymnocranius superciliosus sp. nov. together with other Gymnocranius spp. by setting gillnets on sandy bottom in the southern part of the southern lagoon of Grande Terre close to Kouaré pass, at depths between $15 \mathrm{~m}$ and $30 \mathrm{~m}$. Individual no. JNC-2612 was captured by hand line baited with squid meat on the sandy bottom of Boulari Pass (depth $20 \mathrm{~m}$ ). The stomach of specimen IRDN-20080426 contained broken bivalve shells; that of specimen JNC-2912 contained scraps of urchin shell. Its predatory behaviour has been briefly described by Coleman [4]: “ [...] usually a solitary animal [which] swims a few meters from the bottom, making short forays to the sandy sea floor to investigate any movement which might indicate the presence of prey [...]". An isolated individual was seen and photographed by P. Borsa, about $1 \mathrm{~m}$ above the sandy bottom at $22 \mathrm{~m}$ depth in the pass west of Pulau Fam, West Papua (Supplementary material, Fig. S1F).

\section{Gymnocranius satoi sp. nov.}

Gymnocranius satoi sp. nov. (Table 2; Fig. 3). Previously referred to as G. lethrinoides (non Bleeker 1850 [5]) [6]; Gymnocranius sp. [1,2,20,21]; Gymnocranius sp. C [8-10,12].

\subsection{Vouchers and holotype}

Material examined (Table 2; Fig. 3; Supplementary material, Fig. S1): IRDN-20071124-G3; IRDN20080131-A; JNC-583; JNC-3055; MNHN 2011-0103 (see below). 
We chose as holotype specimen MNHN 2011-0103. This specimen was purchased the Kedonganan (Bali) fish market. Vendors at the market claimed the fish originated from Lombok or West Sumbawa (F. Giancarlo, pers. comm.). However, subsequent interviews with fish vendors in Bali and Lombok have yielded inconsistent and therefore unreliable indications on the origin of the catches in some instances (P. Borsa, pers. obs.; A. Sembiring, pers. comm.). One should therefore consider this specimen to originate from a region of several hundred kilometres radius centred in southern Bali, which is the range reported for the fishing boats that land their catch in Kedonganan [22]. Measurements on the holotype are reported in Table 2.

\subsection{Diagnostic description}

The following description of Gymnocranius satoi sp. nov. is based on the four specimens whose measurements are given in Table 2. Morphology: a high-bodied Gymnocranius, with ratio of standard length to body depth between 2.39 and 2.45 (Table 2); forehead bumpy; lower edge of eye well above axis of body; caudal fin shallowly forked, its lobes convex on inner side. Number of scale rows above lateral line: 6. Pored scales on lateral line: 47-50 (Table 2). Colour: flanks silvery; scales above the lateral line with a dark-grey basal patch forming longitudinal rows; scales in the 3 rows below lateral line in middle of flank similarly forming darker rows, but basal patch not as dark as above lateral line; blue speckles against bronze background on snout an cheeks, distinctive on fresh, larger individuals, faint on smaller individuals; blue band joining the nostrils on forehead; area immediately above eye (supraorbital shelf) forming a distinctive brownish to blackish eyebrow; more or less conspicuous vertical dark bar crossing the eye; dorsal, pectoral, anal and caudal fins reddish to bright vermilion red; upper lip reddish to red, lower lip white.

Gymnocranius satoi sp. nov. is here described by the nucleotide sequence of its cytochrome $b$ gene (from specimen IRDN-20071124-G3): 5'- A T G G C C A G C C T T C G A A A A A C T C A C C C T C T T C T A AAAAT T G C GAACG A T C AC T A G T C GAC C T A C C A G C C C C AACAAAC A T T T C C G C T T GAT GAAAT T T T G G C T C C C TAC TAGG T C T C T G C T T A A T C G CACAAAT C C T TACTGG C C T C T T C C T C G C T A T A C A C T A CA C C T C T G A T A T C G C T A C A G C A T T C T C C T C C G T A G CA C A C A T T T G C C GA GA T G T A A A C T T C G G A T G G C T T T T C G T A A C C T C C A T G C CA A C G GA G C C T C A T T T T T C T T C A T C T G T A T C T A T C T C CA T A T T G G C C GAGGACT T A C T A C G G C T C C T A C C T A T A CAAA GA A A C T GAAA T A T C G G A G T A G T C C T G C T T C T C C T A G TAA T GA T A A CA G C T T C G T G GG C T A T G T T C T C C C C T GAGGA C AAA T A T C C T T T T GA G G C G C C A C T G T C A T C A C C A A C C T C C T C T C T G C A G T A C C A T A T G T A G G GAA

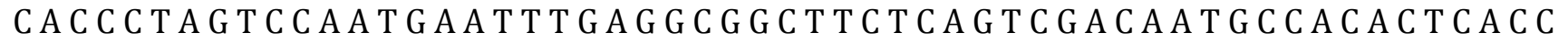
C G A T T C T T C G C C T T C C A C T T C C T C T T C C C C T T C G T C A T T G C A G C T G C A A C C A T C C T C C A C C T T C T G T T C C T A C A C GAAACCG GA T C CAACA A C C C T C T A G G C C T A A A T C A 
GACTCAGACAAAAT T T CAT T C C A C C C C T A C T T C T C G TACAAAGAC C T T C T A G G T T T G C A G C C G T C C T G A T C A C C C T C A C C T G T C T C G C G C T T T T C T C C C C C A A C C T T C T T G G G G A C C C A G A T A A C T T C A C A C C C G C C A A C C C C C T C G T A A C A C C T C C C C A T A T T A

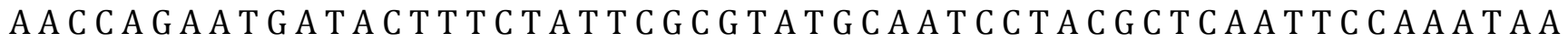
A C T T G G C G GA G T A C T C G C A C T C C T A G C T T C C A T C C T G G T T C T C A T G G T A G T G C C T A T C C T C C A C A C A T C T A A A C A A C GAAG C T T G A C A T T C C G T C C C A T A A C A CA A T T T C T C T T T T GA G T T C T TA T T G C CAATG TAGC CA T T C T T A C C T GAAT T GGAGGAATG C C T G T A GAACA C C C G T T CAT T A T C A T T G G C C A G G T T G C A T C T C T T C T C T A C T T T T C A C T C T T C C T C G T T G C C A T G C C G C T G GCAAGT T GA T G G GAGAACAAAAATC T A G G T G A G C T -3'

\subsection{Etymology}

Named in the honour of Torao Sato, a Japanese ichthyologist who contributed to the taxonomy of Lethrinidae and who recognized the red-finned Gymnocranius presented in [6] (as "G. lethrinoides") as "distinct from the other Gymnocranius species" [1]. The vernacular name of this species should be Sato's large-eye bream, in replacement of, or in addition to Blacknape large-eye bream, the name previously coined by [2].

\subsection{Notes on distribution and habitat}

Gymnocranius satoi sp. nov. specimens were collected from the southern lagoon of New Caledonia and from Raja Ampat in western West Papua (present work). This species' distribution also includes southern Japan [6], and possibly Australia's Great Barrier Reef, the Solomon Sea, the Bismarck Sea and the whole Pacific-Ocean coast of New Guinea [2]. Additional specimens including the holotype of the species reportedly originate from the Lesser Sunda islands, Indonesia, but we were unable to independently confirm this. From the limited data available from New Caledonia (J.-L. Justine, pers. comm.), it seems that this species dwells on the coral sandy bottom at depths between $20 \mathrm{~m}$ and $40 \mathrm{~m}$ in the vicinity of coral reefs.

\section{Discussion}

The two species described here are reproductively isolated from each other $[8,10]$ hence they fit the definition of biological species [23]. While colour patterns are similar between the two species, they mainly differ by the ratio of standard length to body depth and by the shape of the caudal fin. 
In his brief description of Gymnocranius sp. [1], T. Sato mentioned a "caudal fin shallowly forked, its lobes rounded": this feature points to Gymnocranius satoi sp. nov. and much less so to Gymnocranius superciliosus sp. nov., which has a moderately forked caudal fin and moderately curved and relatively elongated lobes. The specimen photographed by Masuda et al. [6] (as "G. lethrinoides") and the description and drawing of Gymnocranius sp. by Carpenter and Allen [2] both correspond to Gymnocranius satoi sp. nov. Although Sato [1] included Coleman's [4] “G. griseus” specimen in his definition of Gymnocranius sp., the latter is different from Masuda et al.'s [6] "G. lethrinoides" and instead matches the present description of Gymnocranius superciliosus sp. nov. by the relative elongation of its body and by the shape of its caudal fin, which are two characters diagnostic of the latter. An underwater picture of Gymnocranius superciliosus sp. nov. (from Fiji) has also been published by [19] under "Gymnocranius species". The authors redirect the reader to Carpenter and Allen's [2] identification sheet of "Gymnocranius sp.", although the description and drawing provided in the latter designate another species (the one here described as Gymnocranius satoi sp. nov.). Thus, two distinct species (namely, Gymnocranius superciliosus sp. nov. and Gymnocranius satoi sp. nov.) have long been confused in the specialized literature under the single term "Gymnocranius sp.". We hope that the present work offers the clarification needed to resolve the apparent mismatch between Coleman's [4] and Allen and Erdmann's [19] illustrations on the one side, and the descriptions of Gymnocranius sp. provided by Sato [1] and Carpenter and Allen [2] on the other side.

Gymnocranius superciliosus sp. nov. and Gymnocranius satoi sp. nov. can be distinguished from all other kown Gymnocranius species (except G. euanus) by their reddish pectoral, dorsal, anal and caudal fins. They are distinct from $G$. euanus by their general body shape and by their pigmentation patterns: $G$. euanus has apparently randomly distributed blackish scales on flanks [2], a feature that is not present in either Gymnocranius superciliosus sp. nov. or Gymnocranius satoi sp. nov. The two latter can also be distinguished from G. elongatus, G. euanus, G. grandoculis and G. oblongus from the Coral Sea and adjacent regions by diagnostic nucleotides along the 315-bp fragment of the cytochrome- $b$ gene sequenced by [8] (Fig. 4).

Monogenean parasites usually are specific to a fish species [12]. Assuming this, it is intriguing to observe that Gymnocranius superciliosus sp. nov. is parasitized by the same monogenean species (Lamellodiscus magnicornis, L. parvicornis and L. tubulicornis) as those encountered in up to three other sympatric Gymnocranius spp. [12]. This may indicate genetic divergence between the four Gymnocranius species too recent to have lead to the ecological specialization and speciation of their Lamellodiscus spp. parasites. Nevertheless, one cannot discard the hypothesis that the Lamellodiscus spp. found on Gymnocranius spp. are actually host-specific, but include a number of morphologically cryptic species.

The Nouméa fish market boasts coral-reef fishes captured in the southern, the north-western, and the northern reefs and lagoons of New Caledonia. Five Gymnocranius species (G. euanus, G. grandoculis, G. oblongus, Gymnocranius satoi sp. nov. and Gymnocranius superciliosus sp. nov.) are regularly seen on the 
stalls there, with the first two species being the most frequently occurring (A. Collet and P. Borsa, pers. obs.). Nearly every month from 2002 to 2010, our IRD colleague J.-L. Justine has used handlines above the reef and coral-reef sandy bottom between 20 and $40 \mathrm{~m}$ in the passes of the southern lagoon of New Caledonia, to collect fishes. Gymnocranius spp. catches were distributed as following: 75\% G. euanus, 15\% G. grandoculis, 4\% G. oblongus, 2\% Gymnocranius satoi sp. nov., and 4\% Gymnocranius superciliosus sp. nov $(N=100)$ (from the photograph files of J.-L. Justine, pers. comm.). During two expeditions to the Chesterfield islands in October 2008 and May 2012, handline fishing and spearfishing on sandy bottom at 5-25 $\mathrm{m}$ in the southern lagoon yielded 95\% G. euanus and 5\% Gymnocranius superciliosus sp. nov. (N=42) (P. Borsa, pers. obs.). From these observations it appears that the three Gymnocranius species that we recently described, namely G. oblongus [10], Gymnocranius satoi sp. nov. (this study) and Gymnocranius superciliosus sp. nov. (this study), are less abundant than G. euanus and G. grandoculis in the catches. Their inferred relative rarity may explain why they have long remained overlooked despite a number of underwater visual surveys of shore fishes in the Coral Sea and adjacent regions [24-29].

\section{Disclosure of interest}

The authors have no conflicts of interest concerning this article.

\section{Acknowledgements}

We are grateful to A. Collet (IRD, Nouméa) for help with sampling, photographing and preserving two of the type specimens, and for excellent assistance with genetic analyses; to A. Cheype (IRD, Nouméa), D. Deschamps (fisherman and fish merchant at the Nouméa fish market), J.-L. Justine (MNHN / IRD, Nouméa), the Li-Khau family (Nouméa fish market), L. Olonde (Nouméa fish market), J. Palene (Marine nationale, Nouméa) and anonymous West Papuan fishermen at the Sorong fish market for donating specimens and /or tissue samples; to C. Cristofoli, F. Giancarlo, and A. Wulandari (U. Seblas Maret, Surakarta) for purchasing fishes at the Kedonganan fish market and for details concerning the possible origin of specimen MNHN 2011-0103; to R. Causse and P. Pruvost (MNHN) for taking care of the fish specimens under their responsibility; to C. Sand (Institut d'archéologie de la Nouvelle-Calédonie et du Pacifique, Nouméa), D. Ponton (IRD), A. Rivaton (Adecal, Nouméa) and P. Chavance (ZoNéCo, Nouméa) for support. J.-L. Justine also provided excellent photographs of the specimens in his catalogue, encouraged us to finalize the present work, and provided helpful comments to the final version of the manuscript. P. Borsa's underwater observations of Gymnocranius superciliosus sp. nov. in Raja Ampat (West Papua) were made during KR Baruna Jaya VIII Ekspedisi Widya Nusantara of LIPI (Jakarta, Indonesia) in partnership with M. Adrim (LIPI-P20, Ancol, Indonesia). C.A.J. Duffy's (Department of Conservation, Auckland, New Zealand) capture of a Gymnocranius superciliosus sp. nov. specimen in 
Tuvalu was part of an NZAid-funded marine biodiversity survey. Sampling in Fiji was during a workshop funded by Agence française de développement, with the assistance of D. Lecchini (IRD) and S. Bala (University of the South Pacific, Suva, Fiji). Funded by IRD-UR 128 / UR 227, a Fonds pacifique pour le développement grant to P. Borsa, ZoNéCo - Opération "Jeunes poissons" grants to P. Borsa and D. Ponton, Taiwan National Science Council grant no. NSC 101-2611-M-002-016-MY3 to W.-J.C., and by personal contributions from P. Borsa, C. Cristofoli, F. Giancarlo, and S.P. All experiments reported here complied with the current laws and regulations of New Caledonia and West Papua. Designed the study: P. Béarez, P. Borsa, W.-J.C.; contributed reagents or materials or analysis tools: P. Borsa, W.-J.C., S.P.; analyzed and interpreted the data: P. Béarez, P. Borsa, W.-J.C.; wrote the paper: P. Borsa.

\section{References}

[1] T. Sato, A systematic review of the sparoid fishes of the subfamily Monotaxinae, In T. Uyeno, R. Arai, T. Taniuchi, K. Matsuura, (eds.), Indo-Pacific fish biology: proceedings of the second international conference on Indo-Pacific fishes, Ichthyological Society of Japan, Tokyo, 1986, pp. 602-612.

[2] K.E. Carpenter, G.R. Allen, FAO species catalogue, vol. 9, Emperor fishes and large-eye breams of the world (family Lethrinidae), An annotated and illustrated catalogue of lethrinid species known to date, FAO Species Synopsis 125, 1989, $118 \mathrm{p}$.

[3] C.J. Temminck, H. Schlegel, Pisces, In P.F. von Siebold, Fauna Japonica, sive descripto animalium quae in itinere per Japoniam suscepto annis 1823-30 collegit, etc., Lugduni, Batavorum, 1842-1950, 323 p., 160 pls.

[4] N. Coleman, Australian sea fishes north of $30^{\circ}$ S, Doubleday, Sydney, 1981, 297 p.

[5] P. Bleeker, Faunae ichthyologicae Javae insularumque adjacentium, Genera et species novae, Nat. Tijdschr. Ned.-Indië, 1 (1850) 98-108.

[6] H. Masuda, K. Amaoka, C. Araga, T. Uyeno, T. Yoshino, The fishes of the Japanese Archipelago, Tokai Univ. Press, Tokyo, 1984, xxii+437 p., 370 pl.

[7] P. Béarez, First record of Scolopsis taeniopterus (Nemipteridae) and Gymnocranius elongatus (Lethrinidae) from New Caledonia, Cybium 27 (2003) 61-62.

[8] P. Borsa, S. Lemer, W.-J. Chen, A. Collet, L. Carassou, D. Ponton, Identification par barcode (séquences nucléotidiques d'un fragment du gène du cytochrome $b$ ) des larves de Lethrinidae capturées en baies de Dumbéa et Ouano (NouvelleCalédonie), Rapport pour Zonéco, IRD, Nouméa, 2009, 60 p.

[9] P. Borsa, A. Collet, L. Carassou, D. Ponton, W.-J. Chen, Multiple nuclear and mitochondrial genotyping identifies emperors and large-eye breams (Teleostei: Lethrinidae) from New Caledonia and reveals new large-eye bream species, Biochem. Syst. Ecol. 38 (2010) 370-389.

[10] P. Borsa, P. Béarez, W.-J. Chen, Gymnocranius oblongus (Teleostei: Lethrinidae), a new large-eye bream species from New Caledonia, C. R. Biol. 333 (2010) 241-247.

[11] J.-L. Justine, M.J. Briand, Three new species, Lamellodiscus tubulicornis n. sp., L. magnicornis n. sp. and L. parvicornis n. sp. (Monogenea: Diplectanidae) from Gymnocranius spp. (Lethrinidae: Monotaxinae) off New Caledonia, with proposal of the new morphological group 'tubulicornis' within Lamellodiscus Johnston \& Tiegs 1922, Syst. Parasitol. 75 (2010) 159-179.

[12] J.-L.Justine, I. Beveridge, G.A. Boxshall, R.A. Bray, F. Moravec, I.D. Whittington, An annotated list of fish parasites (Copepoda, Monogenea, Digenea, Cestoda and Nematoda) collected from Emperors and Emperor Bream (Lethrinidae) in New Caledonia further highlights parasite biodiversity estimates on coral reef fish, Zootaxa, 2691 (2010) 1-40. 
[13] T. Senta, A new sparoid fish, Gymnocranius elongatus from the southern South China Sea, Jap. J. Ichthyol. 20 (1973) $135-144$.

[14] A. Günther, Notice of two new species of fishes from the south seas (Diagramma giganteum, Sphaerodon euanus), Ann. Mag. Nat. Hist. 5 (1879) 136-137.

[15] A. Valenciennes, Livre sixième, partie I, Des Sparoïdes, in G. Cuvier, A. Valenciennes (Eds.), Histoire naturelle des poissons, tome sixième, F.G. Levrault, Paris, 1830, pp. 1-380, pls. 141-163.

[16] A. Lo Galbo, K.E. Carpenter, D.L. Reed, Evolution of trophic types in emperor snappers (Lethrinus, Lethrinidae, Percoidei) based on cytochrome $b$ gene sequence variation, J. Mol. Evol. 54 (2002) 754-762.

[17] T.A. Hall, BIOEDIT: a user-friendly biological sequence alignement editor and analysis program for Windows 95/98/NT, Nucl. Acids Symp. Ser. 41 (1999) 95-98.

[18] P. Borsa, Mission ornithologique à l'îlot Loop (îles Chesterfield) et transects en mer de Corail et dans le bassin des Loyauté, 20-28 octobre 2008, IRD, Nouméa, 2008, 13 p.

[19] G.R. Allen, M.V. Erdmann, Reef fishes of the East Indies, vols. I-III, Tropical Reef Research, Perth, 2012, 1292 p.

[20] K.E. Carpenter, Lethrinidae - emperors (emperor snappers), in: K.E. Carpenter, V.H. Niem (Eds.), FAO species identification guide for fishery purposes, The living marine resources of the Western central Pacific, vol. 5: Bony fishes part 3 (Menidae to Pomacentridae), FAO, Rome, 2001, pp. 3004-3050.

[21] J.E. Randall, G.R. Allen, R.C. Steene, Fishes of the Great Barrier Reef and Coral Sea, Crawford, Bathurst, 1997 (557 p.)

[22] S.J.M. Blaber, C.M. Dichmont, W. White, R. Buckworth, L. Sadiyah, B. Iskandar, S. Nurhakim, R. Pillans, R. Andamari, Dharmadi, Fahmi, Elasmobranchs in southern Indonesian fisheries: the fisheries, the status of the stocks and management options, Rev. Fish Biol. Fisheries 19 (2009) 367-391.

[23] E. Mayr, Systematics and the origin of species, Columbia University Press, New York, 1942, 334 p.

[24] J.E. Randall, G.R. Allen, R.C. Steene, Fishes of the Great Barrier Reef and Coral Sea, Crawford House Press, Bathurst, 1990, xx $+506 \mathrm{p}$.

[25] L. Wantiez, Les poissons des fonds meubles du lagon nord et de la Baie de St Vincent de Nouvelle-Calédonie, Description des peuplements, Structure et fonctionnement des communautés, Thèse de doctorat, Université Aix-Marseille II, Marseille, 1992, $444 \mathrm{p}$.

[26] M. Kulbicki, P. Labrosse, Y. Letourneur, Stock assessment of commercial fishes in the northern New Caledonian lagoon, 2 Lagoon, bottom and near reef fishes, Aquat. Living Resour. 13 (2000) 77-90.

[27] P. Laboute, R. Grandperrin, Poissons de Nouvelle-Calédonie, Catherine Ledru, Nouméa, 2000, 520 p.

[28] J.E. Randall, Reef and shore fishes of the South Pacific: New Caledonia to Tahiti and the Pitcairn Islands, University of Hawai'i Press, Honolulu, 2005, 707 p.

[29] M. Kulbicki, G. MouTham, Résultats des campagnes de pêches expérimentales à la palangre dans le lagon sud-ouest de Nouvelle Calédonie, Rapport Zonéco, IRD Nouméa, 2006, 68 p. 


\section{Table 1}

Measurements on specimens of Gymnocranius superciliosus sp. nov., listed by increasing size. MNHN Museum national d'histoire naturelle, Paris; JNC J.-L. Justine's catalogue, Nouméa; IRDN Institut de recherche pour le développement, centre de Nouméa; $S L$ standard length; $B D d$ body depth at origin of dorsal fin; $B D a$ body depth at origin of anal fin

\begin{tabular}{|c|c|c|c|c|c|c|c|c|c|}
\hline \multirow[t]{3}{*}{ Parameter } & \multicolumn{9}{|l|}{ Specimen no. } \\
\hline & MNHN ICOS- & MNHN & MNHN & MNHN & MNHN & JNC- & IRDN- & IRDN - & IRDN - \\
\hline & $00715^{\text {a }}$ & $2009-0011^{a}$ & $2009-0013^{a}$ & $2009-0012^{a}$ & $2009-0010^{b}$ & 2912 & 20081022 & Z179 & 20080426 \\
\hline$\overline{\mathrm{SL}}(\mathrm{mm})$ & 214 & 220 & 260 & 311 & 323 & 344 & 387 & 419 & 430 \\
\hline BDd (mm) & 79 & 77 & 98 & 106 & 118 & 127 & 142 & 137 & 161 \\
\hline Ratio of SL to BDd & 2.71 & 2.86 & 2.65 & 2.93 & 2.74 & 2.71 & 2.73 & 3.06 & 2.67 \\
\hline BDa (mm) & 75 & 77 & 92 & 99 & 110 & 114 & 122 & 129 & 148 \\
\hline Head length (mm) & 63 & 70 & 86 & 96 & 105 & 101 & 132 & 120 & 135 \\
\hline Snout length (mm) & 24 & 30 & 35 & 42 & 48 & 45 & 66 & 54 & 60 \\
\hline Eye diameter (mm) & 21 & 22 & 27 & 27 & 29 & 30 & 37 & 33.5 & 30 \\
\hline Inter-orbital width (mm) & - & 25 & 30 & 36 & 36 & - & - & 45 & - \\
\hline Predorsal length (mm) & 76 & 79 & 90 & 113 & 118 & 120 & 148 & 136 & 153 \\
\hline Prepelvic length (mm) & 72 & 76 & 91 & 107 & 114 & 129 & 157 & 155 & 153 \\
\hline Preanal length (mm) & 128 & 137 & 166 & 196 & 202 & 219 & 255 & 248 & 279 \\
\hline Pored scales, lateral line & 48 & 48 & 48 & 49 & 48 & 49 & 48 & 49 & 48 \\
\hline
\end{tabular}

a paratype

b holotype 


\section{Table 2}

Measurements on specimens of Gymnocranius satoi sp. nov., ranked by increasing size (except specimen JNC583). Abbrevations as in legend to Table 1.

\begin{tabular}{lccccc}
\hline Parameter & \multicolumn{3}{l}{ Specimen } & & \\
\cline { 2 - 5 } & IRDN- & JNC-3055 & MNHN & IRDN- & JNC-583 \\
& $20080131-A$ & & $2011-0103$ a & $20071124-G 3$ & \\
\hline SL (mm) & 303 & 344 & 397 & 422 & - \\
BDd (mm) & 127 & 142 & 166 & 172 & - \\
Ratio of SL to BDd & 2.39 & 2.42 & 2.39 & 2.45 & 2.40 \\
BDa (mm) & 114 & 123 & 148 & 153 & - \\
Head length (mm) & 100 & 106 & 119 & 130 & - \\
Snout length (mm) & 37 & 49 & 48 & 57 & - \\
Eye diameter (mm) & 31 & 36 & 40 & 38 & - \\
Inter-orbital width (mm) & - & - & 46 & - & - \\
Predorsal length (mm) & 114 & 127 & 140 & 162 & - \\
Prepelvic length (mm) & 109 & 124 & 145 & 163 & - \\
Preanal length (mm) & 197 & 215 & 247 & 271 & - \\
Pored scales on lateral line & 47 & 49 & 48 & 49 & 49 \\
\hline
\end{tabular}

aholotype 


\section{FIGURE CAPTIONS}

FIG. 1. Gymnocranius sp. B specimens chosen as paratypes of Gymnocranius superciliosus sp. nov. A. Specimen from New Caledonia, standard length (SL) $265 \mathrm{~mm}$; skeleton preserved in the ichthyological collections of the Museum national d'histoire naturelle, Paris as MNHN ICOS-00715. B. MNHN 2009-0011, southern lagoon of New Caledonia's Grande Terre, SL 220 mm. C. MNHN 2009-0012, New Caledonia, SL 311 mm. D. MNHN 2009-0013, Viti Levu, SL 260 mm

FIG. 2. Holotype of Gymnocranius superciliosus sp. nov., registered at Museum national d'histoire naturelle, Paris, no. MNHN 2009-0010; SL $323 \mathrm{~mm}$. Scale bar: $5 \mathrm{~cm}$

FIG. 3. Holotype of Gymnocranius satoi sp. nov., registered at Museum national d'histoire naturelle, Paris, under no. MNHN 20110103; SL $397 \mathrm{~mm}$. Scale bar: $5 \mathrm{~cm}$

FIG. 4. Polymorphic nucleotide sites at the cytochrome b locus in six Gymnocranius species (G. elongatus, G. euanus, G. grandoculis, G. oblongus, Gymnocranius superciliosus sp. nov., Gymnocranius satoi sp. nov.) from the Coral Sea and adjacent regions. Point mutations diagnostic of Gymnocranius superciliosus sp. nov. and Gymnocranius satoi sp. nov. relative to the other species are highlighted. The sequence used as reference is that of an uncatalogued specimen of G. elongatus lodged at the Australian Museum, Sydney (AMS), GenBank accession no. AF381260 [16]; numerotation of nucleotide sites starts from first nucleotide of the cytochrome $b$ gene. IRDN Institut de recherche pour le développement, Nouméa; MNHN Museum national d'histoire naturelle, Paris. Sequence of individual IRDN-20071124-G3 from present survey; all other sequences from [8,16]. 

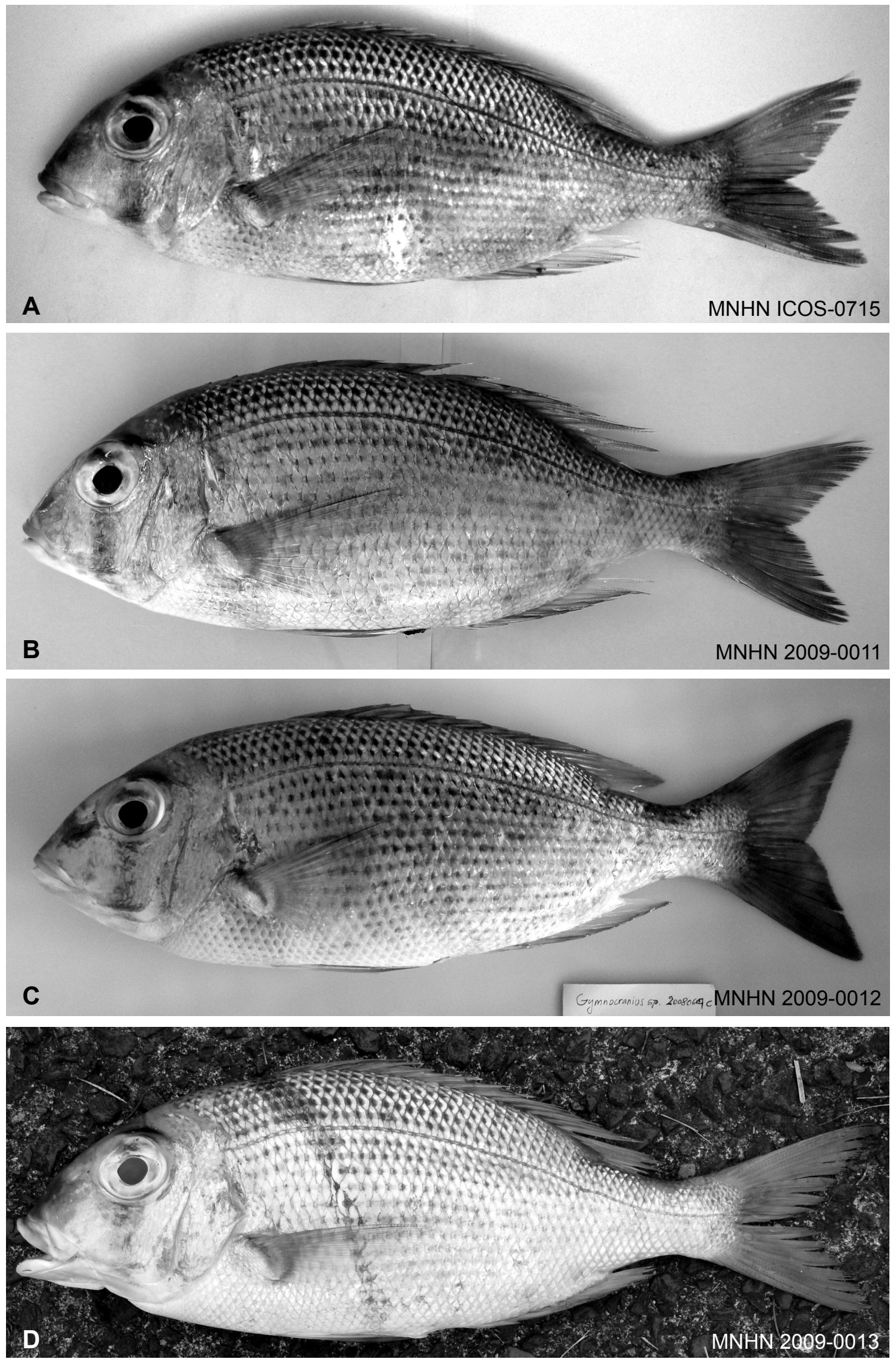


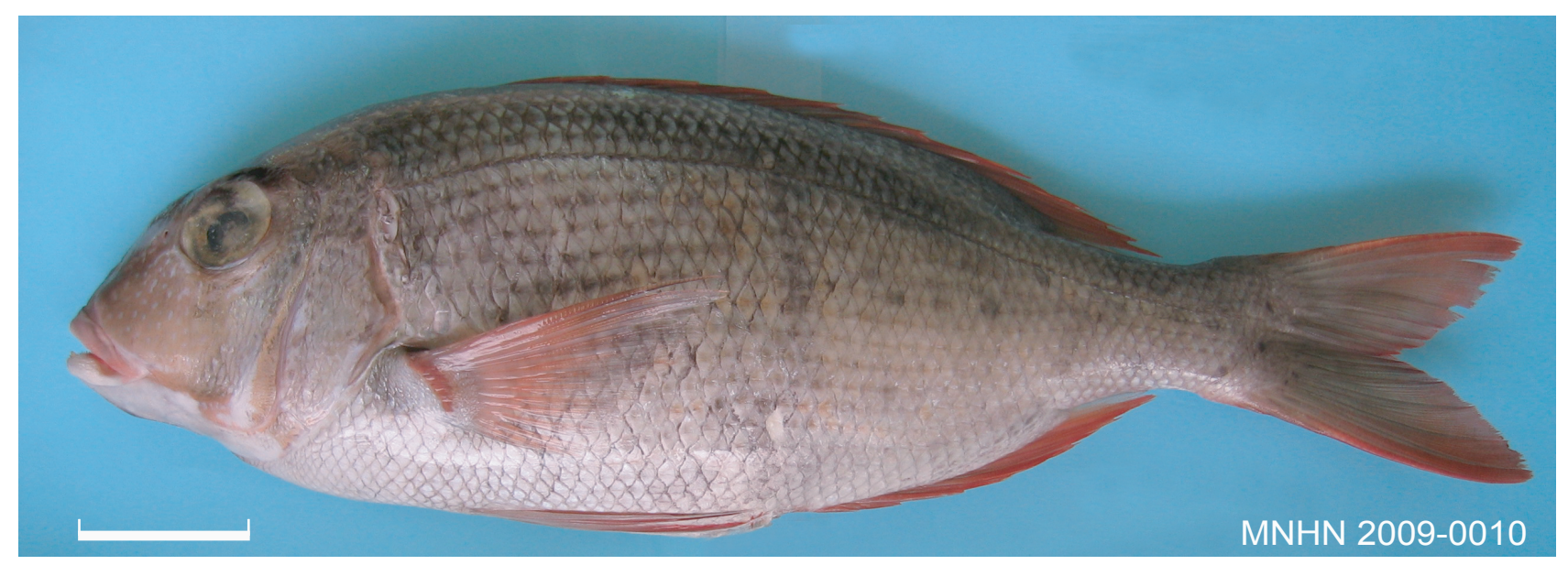




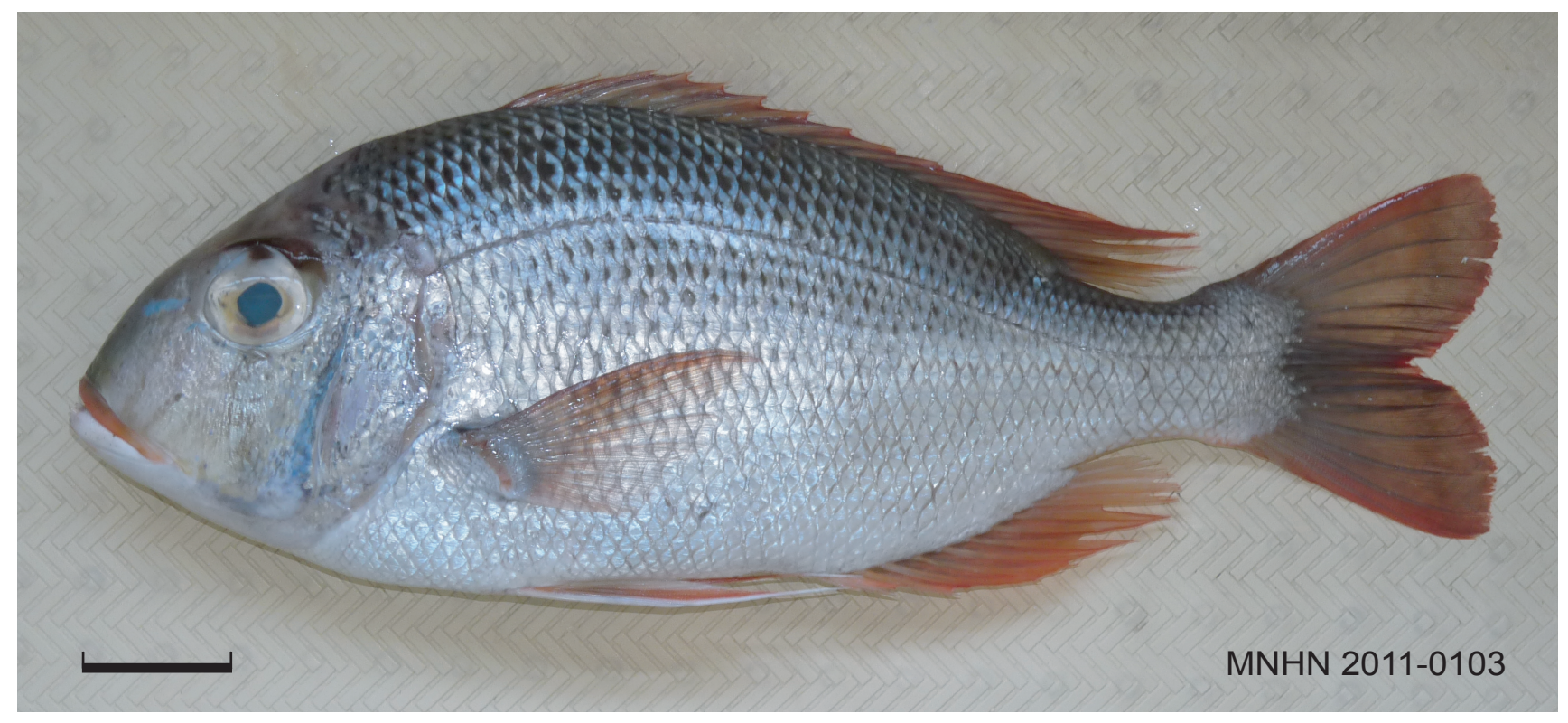


11111111111111111111111122222222222222222222223333

111223334455666677889900011122334445567788899900112233344445556678990001 369158140392517036925780626814709681480651403925814062514703692581468143692

G. elongatus

AMS uncat. (AF381260)

ATTGGTCTTTCATCCTCTCTCACACCTGTGGCTACGCCGGTGATTAAAGTCTATCCTCTATTAGTCCCCACCGCT

G. euanus

MNHN 2007-1610

G. grandoculis

AMS uncat. (AF381275)

IRDN-z177

IRDN-z320

G. oblongus

MNHN 2009-0007

IRDN-z293

IRDN-z294

G. superciliosus sp. nov.

MNHN 2009-0010

MNHN 2009-0011

IRDN-z306

G. satoi sp. nov

IRDN-z305

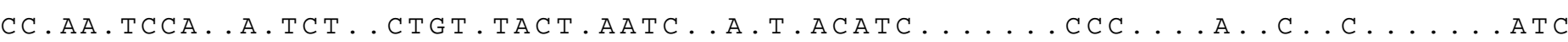

IRDN-20071124-G3

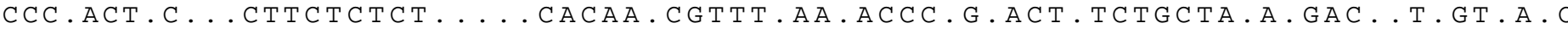

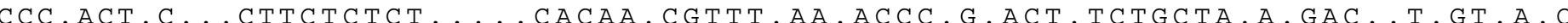
CCC.ACT.C...СTTCTCTCT. ... CACAA. CGTTT.AA. ACCC.G.ACT.TCTGCTA.A.GAC..T.GT.A.C

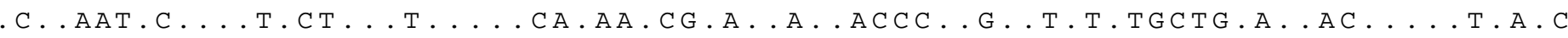

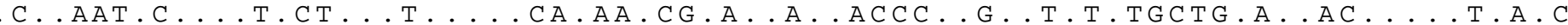

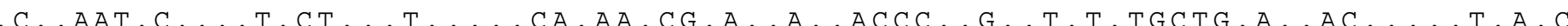

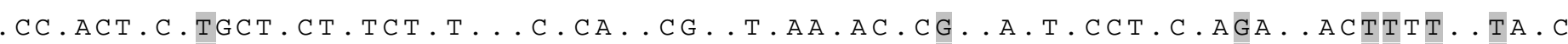

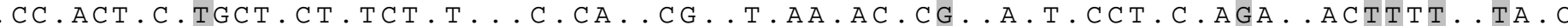

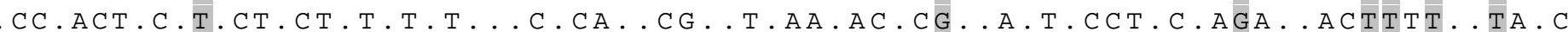

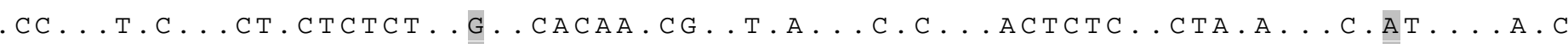

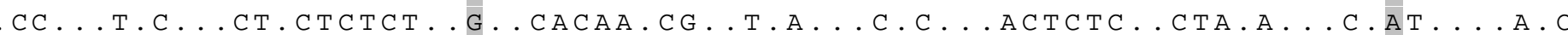


Supplementary material to: "Gymnocranius superciliosus and G. satoi, two new large-eye breams (Sparoidea: Lethrinidae) from the Coral Sea and adjacent regions"

Philippe Borsa, Philippe Béarez̧, Sobar Paijo and Wei-Jen Chen 

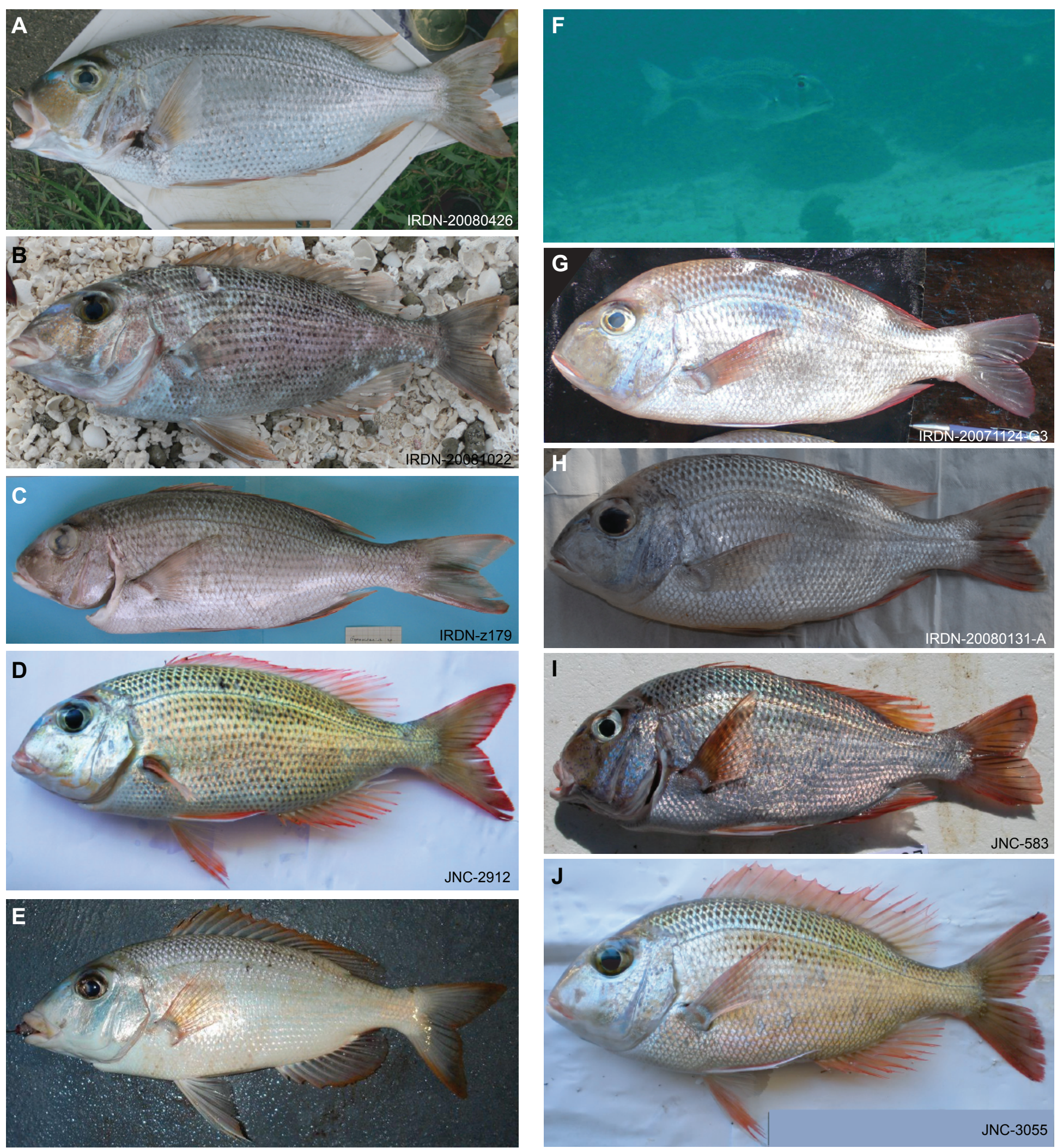

Fig. S1 Large-eye bream specimens examined for the present study, other than type material. A Gymnocranius superciliosus sp. nov., IRDN- 20080426, from coral sandy bottom (depth $7 \mathrm{~m}$ ) off Pindai, northwestern lagoon, New Caledonia, 26 April 2008; caught by A. Cheype (IRD, Nouméa) using a speargun; neurocranium preserved (photograph: P. Borsa / IRD). B Gymnocranius superciliosus sp. nov., IRDN-20081022, from coral sandy bottom (depth $5 \mathrm{~m}$ ) of Loop Islet in the southern lagoon of the Chesterfield islands, Coral Sea, 22 October 2008; caught by J. Palene (Marine nationale, Nouméa) using a speargun (photograph: P. Borsa / IRD). C Gymnocranius superciliosus sp. nov., IRDN-z179 from the northern lagoon of New Caledonia; purchased from the Noumea fish market by P. Borsa, 21 December 2004; neurocranium preserved (photograph: A. Collet / IRD). D Gymnocranius superciliosus sp. nov., JNC-2912, from the sandy bottom north of Tomboo Reef (depth 20-30 m), southwestern lagoon, New Caledonia, 21 April 2009; caught by handline by J.-L. Justine, N. Colombani and M. Briand (IRD, Noumea); neurocranium preserved (photograph: J.-L. Justine / IRD). E Gymnocranius superciliosus sp. nov., southwestern lagoon of Nukufetau Atoll, Tuvalu, 21 April 2007; caught by handline on a "small patch reef surrounded by sand at 15-20 m depth" (photograph: C.A.J. Duffy

/ Department of Conservation, Auckland). F Gymnocranius superciliosus sp. nov., specimen sighted underwater one meter above the coral sandy bottom (depth: 22 m) off Pulau Fam, West Papua, 02 December 2007 (photograph: P. Borsa / IRD / LIPI Ekspedisi Widya Nusantara). G Gymnocranius satoi sp. nov., specimen IRDN-20071124-G3 from Raja Ampat, West Papua; sampled at the Sorong fish market by S.P., 24 November 2007; fin clip preserved (photograph: S.P. / BioKor). H Gymnocranius satoi sp. nov., IRDN-20080131-A, Lesser Sunda islands; sampled at the Kedonganan fish market by F.

Giancarlo and C. Cristofoli, 31 January 2008; fin clip preserved (photograph: F. Giancarlo / BioKor). I Gymnocranius satoi sp. nov., JNC-583, from the sandy bottom of Le Sournois Reef (depth $20-40 \mathrm{~m}$ ), southwestern lagoon, New Caledonia (22 $31^{\prime} \mathrm{S}, 166^{\circ} 26^{\prime} \mathrm{E}$ ), 01 July 2003 ; caught by handline by J.-L. Justine and students (photograph: J.-L. Justine / IRD). J Gymnocranius satoi sp. nov., JNC-3055, from the coral sandy bottom (depth 20-40 m) of the pass east of Tomboo Reef, southwestern lagoon, New Caledonia $\left(22^{\circ} 34^{\prime}\right.$ S 166 $\left.29^{\prime} E\right), 16$ September 2009; caught by handline by J.-L. Justine, C. Schoelinck, E. Henry and S. Tereua; tissue preserved (photograph: J.-L. Justine / IRD). 